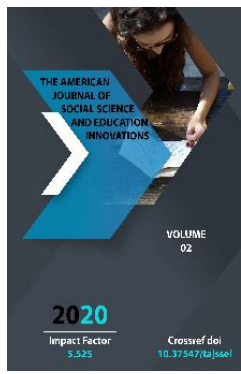

\title{
Typology Of Materials On The Environmental Topic In The Media Of Uzbekistan
}

\author{
Nargis Sunnat kizi Kosimova \\ Phd In Philology, Associate Professor Faculty Of International Journalism Uzbek State \\ University Of World Languages Tashkent, Republic Of Uzbekistan
}

Copyright: Original content from this work may be used under the terms of the creative commons attributes 4.0 licence.

\section{ABSTRACT}

The article discusses the issues of classification of materials of the media in Uzbekistan on environmental topics, analyzes the state of environmental journalism in the republic and identifies shortcomings in the presentation of environmental information and its impact on the formation of environmental thinking of the population.

The author of the study revealed and analyzed the shortcomings of the theoretical base on the problems of media coverage of environmental problems, highlight the typology of environmental journalism in Uzbekistan,consider the problems of forming the ecological culture of the population through the media.And also to determine the role of environmental journalism in Uzbekistan in the international information space.

The main results of the research are the analysis of quantitative indicators of journalistic materials on environmental topics. As a result of the study, it was revealed that there is no consistency, genre and thematic diversity in the presentation of environmental information in the media. The expediency of ecological specialization in training journalists is recommended.

\section{KEYWORDS}

Ecology, Uzbekistan, climate change, Aral Sea, UN, mass media.

\section{INTRODUCTION}

During the study period (2010 - the first half of 2020), the media of Uzbekistan, as well as social networks, published materials reflecting the environmental instability not only in 
Uzbekistan, but also in Central Asia as a whole. This is due to the increased attention of the general public to environmental problems, their coverage in the media only from the positive side, the concealment of environmental problems for years (climate change, lack of drinking and irrigation water, land degradation, biodiversity issues, climate change, air pollution, waste problems, etc.) etc.). The problem of the drying up of the Aral Sea, was of great strategic importance not only for Uzbekistan, but also for the Central Asian countries of the region as a whole, became the main topic of discussion back in the 1980s. Over the years, a solution to this problem was not found, but it remained on the pages of print. It should be noted that the attitude of the media to the environmental policy of Uzbekistan was not always unambiguous it traced the ups and downs of the country's environmental policy based on national priorities, economic and political factors.

According to the 2011 report of the International Fund for Saving the Aral Sea on the Aral Sea disaster, from 1993 to 2011, 2,400 articles were published in the print media of Uzbekistan, 13 brochures, books and posters were published, 60 films, videos and clips were created. Over 1000 TV spots, information and reports were broadcast on television. From 2011 to 2019, the number of journalistic materials increased. Only the print media published 1,780 articles on various journalistic genres. Over 640 TV plots and reports were prepared. In addition, various competitions on environmental topics held among students of journalism faculties and representatives of the media contributed to the wide coverage of the problem and attracting attention to the issue of government authorities and the general public $(2 ; 4)$.

At the same time, the growth of media attention to environmental problems cannot be called dynamic; there were ups and downs in it, which were determined mainly by the place of ecology in the system of state policy, by socio-economic factors. This can be especially seen in publications of the early 1990s, when the environmental topic almost disappeared from the pages of print, it was pushed into the background. It was during these years that journalists drew attention to major political changes in the country. Even earlier, the existing censorship in the country limited the possibilities for a broad discussion of environmental problems in the media.

It should be noted that environmental journalism in Uzbekistan has not yet been formed as a separate branch of journalism. There is no separate website or mass media in the country dedicated to the coverage of the water problem. This is also facilitated by the lack of environmental awareness among journalists, specialized media, coverage of the problem mainly by specialists, the presentation of journalistic materials in information genres, as well as mainly the narrative nature of the materials being prepared.

\section{MATERIALS AND METHODS}

The empirical basis of the scientific research was made up of monographs and scientific articles of foreign, Russian and Uzbek researchers, experts in the field of environmental journalism. In general, the author studied journalistic materials on an environmental topic published both in the traditional media of Uzbekistan and in social networks. In the course of work on the topic, legal documents regulating the field of environmental protection and internal editorial documents of the Republic of Uzbekistan, as well as recommendations and guidelines of ecologists on covering the problems of environmental protection were studied. (Cox, Robert and Pezzullo (2010). The typology of environmental topics in the media was identified by us based on published materials in this area (random sample). The tasks were set to consider the model of 
environmental media in Uzbekistan, therefore, we studied sites that have information about media published in Uzbekistan ecological focus, including ekolog.uz, sreda.uz, eko.uz, ecouz.uz, uznature.uz, ecosan.uz, obod.uz.In order to identify the concept of publications, their thematic preferences, the sites of leading traditional and new media were analyzed kun.uz, daryo.uz, gazeta.uz, uza.uz, where environmental information about cases of poaching, illegal felling of trees, bullying of homeless animals is placed.

The study of this issue was carried out within the framework of a study devoted to the study of the formation and development of environmental journalism in Uzbekistan. Therefore, in the study, when classifying journalistic materials covering environmental policy, we chose the method of analysis in the context of environmental problems, since today the Uzbek society has an urgent need for high-quality environmental information to adapt to various environmental changes and risks, including climate change problems. Currently, there is a lack of eco-political communication between the governing bodies and the population. Environmental journalism, in turn, has the ability to solve this problem and meet the needs of the population in this area.

\section{LITERATURE REVIEW}

The classification of journalistic materials on environmental topics is considered in the studies of foreign authors: E. Bourassa, W. Amend, D. Secko (2013), A. Hansen (2011), M. Miless, M. Larouz (2020), E. Friedman (2020), E. A. Sharkova (2012), L. N. Kharchenko (2002), articles by N. V. Shulenina (2006), T. V. Shumilina (2006). The works of L.A. Kokhanova (2007), which give an idea of the stages of the formation of environmental journalism in Russia, are among the key ones in the theory of environmental journalism. Another Russian researcher V.A.Korolev
(2008) talks about the importance of the ecological direction of journalism, defining its functions and tasks. In Uzbekistan, the study of environmental journalism is in its infancy, although certain aspects of the problem of ecology and environmental policy were considered by Kh.Azamov (2014), Yu. Zhuraev, Sh. Zhuraev (2015), Yu. Shodimetov (2018), T. Azizov (2019) and others. Only the work of Zh. K. Marziyayev (2019) was devoted to the problems of the formation of environmental journalism in the Republic of Karakalpakstan, where he considers the coverage in print media of the Aral Sea crisis and the environmental risks associated with it in the Aral Sea region. More research on this topic in Uzbekistan has not been conducted.

\section{RESULTS AND DISCUSSION}

Examining the coverage of environmental problems in the media of Uzbekistan, it turned out that the most urgent, but little-covered topic is the problem of water.

Analysis of materials in the media devoted to water topics showed that the most widespread problem during the research period was covered by the journal "Киқиқ va burch" ("Right and Duty") and its similar web page on the Internet huquqburch.uz, as well as such Internet publications, http: / /www.biznes-daily.uz, www.uza.uz, https://kun.uz, www.xabar.uz, eco.uz, ekolog.uz, sreda.uz. In the period from 2010 to April 1, 2020 in the media, based on its number (as of January 2020, 1,653 registered media outlets operated in Uzbekistan), the water problem was very poorly covered. Journalists mainly pay attention to the topic only during the period of the contests for "The best journalistic material".

In recent years, in order to raise awareness among the population, articles devoted to this issue have been published on the sites http://www.meteomed.uz, http://www.meteo.uz. But despite this, there 
are very few journalistic materials aimed at analyzing the current situation related to climate change. The published materials are of a general nature; they lack comparative statistics. This can be seen in the articles published in the republican newspapers "Khalk sozi", "Zhamiyat", "XX1 asr", in the magazines "Yangi Avlod", "Ecology of Khabarnomasi" and in the online editions sharh.uz, uza.uz.

The Center for Retraining Journalists of Uzbekistan in 2016-2017, with the financial support of the Canadian Foundation for the Support of Civil Initiatives, held a training seminar for media representatives and bloggers on the topic "Increasing the capacity of journalists to cover global climate change". Within the framework of the project, a competition was held for the best coverage of this topic in the media. As a result of the competition and monitoring of materials published in 2010-2017, it was revealed that during this period only 131 journalistic materials on the topic of global climate change were published. And for 2017-2020, 95 materials were published.

Analysis of coverage of environmental problems in the media of Uzbekistan clearly shows that environmental issues are unstable. Another problem is the need to present problems in eco-materials (use clear, simple expressions), the style of publications on environmental topics, overcoming too scientific terms that are incomprehensible to the common man in the street. More visual context should be given in numbers.

When classifying materials for the study period (2010 - May 2020), you can use the classification of sources of environmental information by E.A. Sharkova. Unfortunately, the analyzed materials lack some sources. Such as citizens-witnesses of environmental problems, representatives of NGOs, the opinions of the leaders of the Ecological Party of Uzbekistan are rarely cited in information genres.

\section{CONCLUSION}

It should be noted that the classification of journalistic materials on an environmental topic in the Uzbek media showed that journalists and bloggers of Uzbekistan selectively cover environmental issues. Preference is given to those environmental problems on which the population turns to the media for help. These are tree felling, waste problem, water and water use problem, loss of biodiversity and others. Such problems as global climate change, biodiversity, the problem of drinking and irrigation water, water use, air pollution, land degradation, and so on remain unattended by journalists. The environmental theme is special. It is complex and multifaceted. Often, environmental problems are covered in the media, attracting scientists to the topic. But the complex language, full of scientific terminology, scares the reader away. Most of the analyzed materials are written in a scientific style, which is sometimes difficult to understand not only for the journalist, but also for the population. The mass media are called upon to play an essential guiding role in enhancing environmental knowledge and shaping environmental awareness. Because the life and health of every person is directly related to the state of the environment. Any information on an environmental topic is perceived by the reader sharply, as it affects his life. The media, and recently social networks, are today one of the main sources of environmental information for the population of Uzbekistan. It depends on the media representative, as well as on environmental volunteers, whether readers / viewers / listeners / users will learn about the existing environmental problem in the region, whether the authorities will pay attention to it, whether this material will provoke decisive action to protect the environment. Our conclusion is that these are two sides of the 
same process, it is impossible to declare information openness and prevent the transmission of local authorities by the producers of their environmental achievements. This is basically the work of a journalist: not only to raise an environmental problem and show ways to solve it, but also to identify the results, to highlight them. Unfortunately, there is a lack of in-depth journalistic investigations, a lack of reporting materials.

\section{REFERENCES}

1. Berlova O., Boreiko V., Kolesnikova V., Kochineva A. (2000). How environmentalists work with the media. Kiev: - p. 310.

2. Hansen, A. (2011). Communication, media and environment: Towards reconnecting research 21 on the production, content and social implications of environmental communication. International Communication Gazette, -p. 73.

3. Vasiliev S.L. (1985) Means and ways of orienting the reader in the content of periodicals. Dissertation for the degree of candidate of philological sciences. - Moscow: -p. 206.

4. Dzhumagazieva N.K. (2010). Coverage of environmental problems in the periodicals of Kyrgyzstan (1996-2006), Author's abstract of the dissertation for the degree of candidate of philological sciences. Dushanbe: p.23.

5. Dzhangirov $M$. Development of environmental journalism in Uzbekistan contributes to the dissemination of knowledge. http://www.cac-program.org

6. Kokhanova L.A. (2007). Environmental journalism, PR and advertising. Textbook. Moscow: Unity-Dana. - p. 383.

7. Korolev V.A. (2008). Environmental journalism. Textbook. V. A. Korolev; ed. I. B. Kamynin. Taurida Humanitarian and Environmental Institute (Simferopol). Simferopol: Taurida Humanitarian and Environmental Institute. -p. 109.

8. Kikhtan V.V. (2014). Aspects of coverage of the ecological problem of land degradation in Russian media. Humanities and social sciences, Rostov-on-Don, Russia: No. 2. -pp. 304-307.

9. Unprecedented experience in the world: Uzbekistan is turning the bottom of the Aral Sea into a forest. [Unprecedented experience in the world: Uzbekistan turns the bottom of the Aral Sea into a forest]. https://www.bbc.com/uzbek/uzbekista n-44184863

10. Den Aralskogo morya [Aral Sea Day]. https://aral.uz/wp/2020/03/26/03_26/

11. Mejdunarodniy fond spasenie Arala. [International Fund for Saving the Aral Sea].

https://www.osce.org/ru/uzbekistan/7 5577?download=true 